\title{
SIX RENAISSANCE TRAGEDIES
}




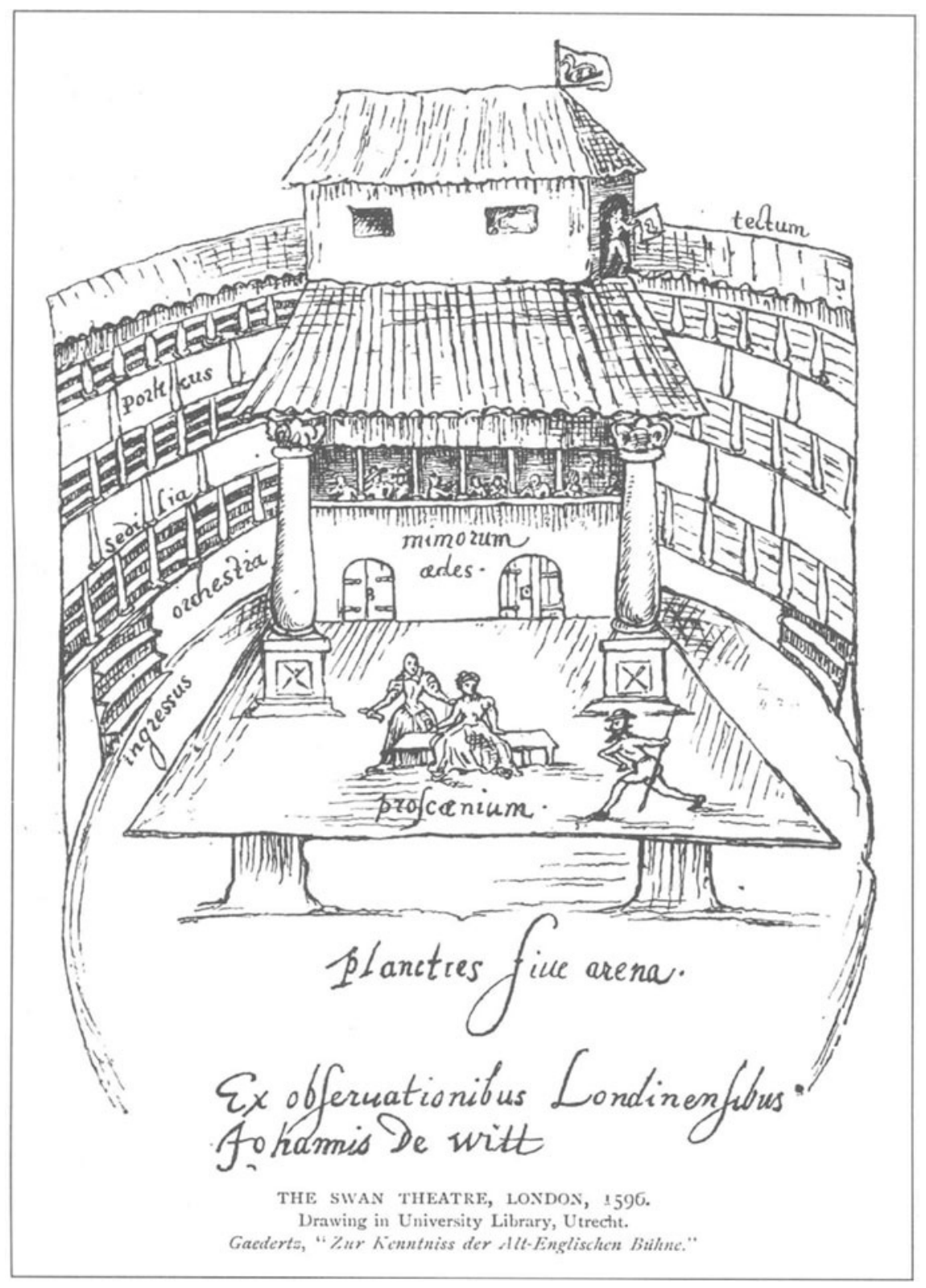

The Swan Theatre

(Source: The Mansell Collection, London) 


\section{Six Renaissance Tragedies}

The Spanish Tragedy

The Tragical History of Doctor Faustus

The Revenger's Tragedy

The Duchess of Malfi

The Changeling

'Tis Pity She's a Whore

Edited by

Colin Gibson

Donald Collie Professor of English

University of Otago, New Zealand

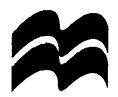

Macmillan Education 
SIX RENAISSANCE TRAGEDIES

Editorial matter and selection copyright $(\odot) 1997$ by Colin Gibson

Softcover reprint of the hardcover 1st edition 1997 978-1-349-25800-0

All rights reserved. No part of this book may be used or reproduced in any manner whatsoever without written permission except in the case of brief quotations embodied in critical articles or reviews.

For information, address:

St. Martin's Press, Scholarly and Reference Division, 175 Fifth Avenue, New York, N.Y. 10010

First published in the United States of America in 1997

This book is printed on paper suitable for recycling and made from fully managed and sustained forest sources.

ISBN 978-0-333-60923-1 ISBN 978-1-349-25800-0 (eBook)

DOI 10.1007/978-1-349-25800-0

Library of Congress Cataloging-in-Publication Data

Six Renaissance tragedies / edited by Colin Gibson.

p. $\mathrm{cm}$.

Includes bibliographical references (p. ) and index.

Contents: The Spanish tragedy - The tragical history of Doctor

Faustus - The revenger's tragedy - The Duchess of Malfi - The changeling - 'Tis pity she's a whore.

ISBN 978-0-312-17549-8 (cloth). — ISBN 978-0-312-17550-4 (pbk.)

1. English drama-Early modern and Elizabethan, 1500-1600.

2. English drama-17th century. 3. English drama (Tragedy)

4. Renaissance-England. I. Gibson, Colin.

PR1263.S55 1997

$822 \cdot .308-\mathrm{dc} 21$ 


\section{Contents}

Frontispiece: The Swan Theatre

Acknowledgements

vii

General Introduction

viii

Note on the Texts

$x x x$

The Spanish Tragedy

Introductory Note

Text

Notes to the Play

The Tragical History of Doctor Faustus

Introductory Note

Text

Notes to the Play

The Revenger's Tragedy

Introductory Note

Text

Notes to the Play

The Duchess of Malfi

Introductory Note

Text

Notes to the Play

\section{The Changeling}

Introductory Note

Text

Notes to the Play 
'Tis Pity She's a Whore

Introductory Note $\quad 429$

Text $\quad 432$

Notes to the Play 495

Appendix I

Introductory Note $\quad 505$

The Spanish Tragedy (1602): the 'Painter Scene' 506

Notes

Appendix II

Introductory Note

511

Doctor Faustus (1616): Act Five

512

Notes

521

Further Reading

525 


\section{Acknowledgements}

I would like to thank Mary Sullivan, Justine Thompson, and Fiona McDonald for expert assistance in preparing the typescript of this anthology. Thanks are due to the Division of Humanities and the University of Otago for generous research grants and research leave, and to Clare Hall, Cambridge, and the Folger Shakespeare Library for visiting fellowships. I am grateful for the willing assistance of the librarians and staff of my own university and of the libraries where I have researched material for this edition. Particular thanks go to the British Library, the Folger Shakespeare Library, the Library of Congress, the University of Cambridge Library and the Bodleian Library, Oxford. I gratefully acknowledge the patience and professional assistance of Macmillan and its staff, in particular, Cathryn Tanner and Margaret Bartley. Valery Rose and Nick Allen scrupulously attended to the copy-editing and setting of the text. More personal but deeply felt thanks are due to Muriel King and Jeanette Gibson for their daily encouragement and unfailing support.

COLIN GIBSON

Dunedin, New Zealand 


\section{General Introduction}

The six plays in this anthology have been chosen to represent a remarkable flowering of tragic dramatic writing during one of the most prolific periods of theatrical activity in any culture, the period known as the English Renaissance, dating from about 1590 to 1640.

The tragedies of the two greatest English dramatists of the period, Shakespeare and Jonson, are not represented here, both because they are readily available and because their absence allows the individual talents of the many writers who were their predecessors, contemporaries and successors to be more clearly displayed. But each of the plays included is both a major work in the dramatic output of its author (or principal author) and - with the possible exception of Kyd's The Spanish Tragedy, important in its own right as a seminal drama for the period - has held its place in the theatre until the present day.

\section{The Tragic Scene}

Tragedy has always enjoyed a senior position in the hierarchy of dramatic kinds, and the interest of the writers and critics of the English Renaissance in the heritage of classical Greek and Roman drama, fostered by school and university study as well as by the publication of texts and translations, ensured that many writers attempted what was widely regarded as the most challenging and important kind of dramatic writing. Comedies might be more popular and enjoyable, but tragedy was admired for its gravity and the seriousness of its subject matter. Thomas Middleton, the co-author of The Changeling, and himself a prolific writer of both tragedies and comedies, contributed a commendatory verse in learned Latin (here given in translation) on the occasion of the publication of Webster's Duchess of Malfi (1623); titled 'Upon Tragedy' it declared that 'Just as light springs from darkness at a 
blow from the Thunderer [Jupiter, king of the gods], so Tragedy, ruinous for bad poets, becomes lasting life for good and famous poets.' To which John Ford, another author of comedies and tragedies including 'Tis Pity She's a Whore, in yet another commendatory verse prefixed to The Duchess of Malfi, added the final accolade for a Renaissance writer, 'Crown him a poet, whom nor Rome nor Greece/Transcend in all theirs, for a masterpiece.'

For such reasons of literary prestige (and doubtless the more pragmatic reason that tragedies could draw audiences), large numbers of such plays were written between 1590 and 1640. Alfred Harbage's Annals of English Drama 975-1700 documents the existence of about 1300 plays datable to the span of fifty years which sets the chronological frame for this collection, with some two hundred claiming the generic name of tragedy. In many cases, the plays are only known by title or from some other fragmentary piece of evidence; and there can be little doubt that many more have vanished, leaving no record whatever. While the six tragedies chosen powerfully present many of the common tragic themes of the period and display something of its variety of forms, within the limits of this anthology it has not been possible to cover the full range of subject matter or comprehensively display the variations within a form explored by so many writers. It will be useful to draw attention to some of the more significant omissions.

Tragedies of state, that is, dramas in which the focus is on the tragic experience of high-ranking individuals within the tumultuous currents of great political events, are not to be found here: plays such as Marlowe's Edward II, dealing with the fall from power and brutal destruction of a weak king, Shakespeare's Coriolanus, with its account of the life and death of a charismatic but deeply flawed military leader made the tool of political manipulators, Jonson's description in Sejanus of the human effects of a corrupt and tyrannical system of political government, or Massinger's depiction in Believe As You List of the politically expedient extermination of a royal claimant. As in Shakespeare's Othello, Kyd's tragic protagonist Hieronimo, in The Spanish Tragedy, works out his personal conflicts in the shadow of a greater war, just as Marlowe can exploit the conflict between Catholicism and the Protestant faith in The Tragical History of Doctor Faustus, but the destruction of a Faustus, or a Giovanni, of a Beatrice-Joanna or a Duchess of Malfi, does not cause or resolve a political crisis.

Nor are there any examples of what have been called 'domestic 
tragedies', plays in which human disasters occur within the framework of bourgeois or middle-class family life realistically portrayed, as in the anonymous tragedy Arden of Faversham, or Heywood's A Woman Killed with Kindness. Not that the majority of plays selected locate themselves exclusively in royal courts or focus on the affairs of kings and nations. Hieronimo is a senior judge associated with the Spanish crown; Faustus occasionally shows off his magic powers in papal and royal settings; Italian dukedoms provide the tragic arena for Vindice in The Revenger's Tragedy and for the Duchess of Malfi. But the action of The Changeling takes place in a nobleman's castle and a doctor's asylum, and the tragic protagonists in Ford's play 'Tis Pity She's a Whore are the children of a well-to-do citizen of Parma.

Although several of the dramatists represented here set the action of their plays at a time before the present time of their audiences (a typical strategy in tragic writing), their primary interests do not lie in the simple reconstruction of remote historical events, either as intrinsically interesting in themselves or as thinly disguised reflections of contemporary realities. The universal capacities and defects of their characters are more important to them than the manners of a past age; there is no representative included here of the many Renaissance tragedies dealing in the style of a dramatised chronicle with the historical lives and deaths of famous Greek, Roman or early medieval figures. (In 1602, early in their careers as playwrights, Webster and Middleton contributed to the teamwriting of such a play (now lost) called Caesar's Fall.)

Finally, though several of the plays selected reflect the English taste for mixed theatrical modes by their inclusion of clown figures, parodic comic scenes or sub-plots, or instances of black humour, none of them exemplifies the tragi-comic forms that became prominent in the last years of the period: plays in which events drive their principal characters towards a total catastrophe which is avoided at the last possible moment, to veer into the reassuring world of comedy and a happy close to lives which have experienced 'the danger but not the death'.

\section{Carnal, Bloody and Unnatural Acts}

It would be easy to make a case for the uniqueness of each of the chosen plays as the expression of their authors' individual sensibility and vision of the world. As Gamini Salgado points out, 
'literary categories are always arbitrary and creative artists have always shown a healthy disrespect for them (if, indeed, they have been aware of their existence)' (Three Jacobean Tragedies [Harmondsworth, 1965] p. 11). But there are significant common elements in these plays, already recognised in their own time.

The first is simply a preoccupation with violence and excess, whether of emotion or action, among the most powerful, cultured and high-ranking members of society. 'The argument of tragedy', declared a hostile Puritan writer, Stephen Gosson, 'is wrath, cruelty, incest, injury, murder either violent by sword or voluntary by poison. The persons gods, goddesses, juries, friends, kings, queens, and mighty men.' Gosson was writing in 1582 , but it would be easy to match his list of topics to these plays. There is indeed a paradoxical relationship between the subject matter of even the greatest tragedies of the period and the genre's reputed gravity and seriousness of theme, well displayed in Horatio's summary of the action of Hamlet (1600):

So shall you hear

Of carnal, bloody, and unnatural acts,

Of accidental judgements, casual slaughters,

Of deaths put on by cunning and forced cause,

And in this upshot, purposes mistook

Fallen on th' inventors' heads.

(5.2.359-64, New Cambridge edition)

This paradox is also recognised by an unknown dramatist of the period, who in the Induction to A Warning for Fair Women (1599) puts into the mouth of Comedy a highly irreverent view of Tragedy. The subject of tragic plays, declares the scoffer, is

How some damned tyrant, to obtain a crown, Stabs, hangs, imprisons, smothers, cutteth throats,

And then a Chorus, too, comes howling in,

And tells us of the worrying of a cat,

Then of a filthy, whining ghost,

Lapped in some foul sheet, or leather pilch,

Comes screaming in like a pig half-sticked,

And cries 'Vindicta, revenge, revenge'.

With that a little resin flasheth forth,

Like smoke out of a tobacco pipe, or a boy's squib. 
Then comes in two or three, like to drovers, With tailors' bodkins, stabbing one another. Is not this trim? is not here goodly things That you should be so much accounted of?

For all the partial truth in such accounts, it is not difficult to recognise that these tragic plays actually have much in common with the comedies of the period. Indeed, some of the tragedies subsume a comic and jeering perspective objectified in characters like Robin and Rafe (Doctor Faustus), aspects of Vindice, Ambitioso and Supervacuo (The Revenger's Tragedy), Bosola (The Duchess of Malfi), Antonio and Franciscus (The Changeling), and Bergetto ('Tis Pity She's a Whore). In particular, they share with comedy an interest in social boundary-breaking (though where the comedies mock, ridicule and reform offenders, tragic stories typically apply the most extreme penalties for such behaviour). Kyd's play concerns itself with the imperative social and religious sanctions against taking human life; Marlowe deals with his (and our own) culture's nervousness about unlimited scientific and philosophical inquiry. The Revenger's Tragedy draws out the consequences of sexual violation and unchecked self-indulgence; in both The Duchess of Malfi and The Changeling the fatal boundary crossed is that of social class distinction and blood line, though the offenders are held within the circle of the audience's sympathies in the first tragedy and moved out to its limits in the second play. Beatrice-Joanna acknowledges her marginalisation in a dying speech to her betrayed husband:

Oh, come not near me, sir, I shall defile you, I am that of your blood was taken from you For your better health; look no more upon't, But cast it to the ground regardlessly:

Let the common sewer take it from distinction... Alsemero, I am a stranger to your bed.

In'Tis Pity She's a Whore, Ford plays off an enervated conventional moral and social order of courtship and marriage against the anti-social behaviour of the faithless but possessive Soranzo, and the 
incestuous brother and sister whose romantic, idealising love for each other breaks the strongest of all sexual taboos.

\section{Why This Is Hell, Nor Am I Out of It}

In all of these tragedies, social sanctions are reinforced with appeals to religious sanctions and invocations addressed to divine authority, though only in Doctor Faustus is God's displeasure at the boundarycrosser's challenge unambiguously declared. However, their grand theme is not so much the mysterious working out of the will of the gods, or the imaginative, emotional and intellectual capacity of some human beings to experience and comprehend the full repertoire of physical and psychological suffering. It is rather the terrifying ability of the human spirit to bring into being and endure hell on earth for itself and others. Such a theme in turn mirrors the dark creative powers of the dramatist, just as it reflects the theatre audience's perennial willingness to enter imaginatively into scenes of agonised suffering or triumphant iniquity.

It is hardly surprising that the greatest tragedies of the period address in such metaphysical terms the experience of the worst that can befall humanity. As a form, tragedy has always located human life and action within the framework of the whole of the natural world and the jurisdiction of whatever powers lie beyond the visible universe. Hieronimo, Faustus, the Duchess of Malfi and Giovanni cry to heaven, challenge the power or apparent indifference of the gods, or puzzle over the ways of providence, just as do Oedipus, Lear, Hamlet, Juno Boyle or Estragon and Vladimir. Ghosts, blazing stars, peals of thunder, the appearance of angels and demons and stage representations of death such as Vindice's 'bony lady' or Bosola's Tomb-maker and Bellman signify the mysterious co-existence of worlds beyond the present one.

It must also be remembered that the playwrights of the English Renaissance were heirs to a vigorous medieval tradition of religious drama, in which the powers of Good and Evil beset and fought to win the souls of humankind, and allegorical figures might hold the stage with representative human characters. The dramaturgical techniques of that tradition are still to be seen in the work of the earliest writers in this anthology: for instance, in the figures of Revenge and the ghost of Andrea brought on stage to brood over the human action of The Spanish Tragedy, or in the appearance of the Good and Bad Angel or the show of the Seven Deadly Sins in The 
Tragical History of Doctor Faustus. Later dramatists work with similar frames of thought but abandon such external stage representation as old-fashioned. When hell is evoked some forty years later in Ford's 'Tis Pity She's a Whore, it is described in vivid pictorial images in the friar's terrifying sermon to Annabella (3.6.8-30), but not introduced as a stage property.

The plays in this anthology are distinguished not so much by their incorporation of such an explicit or implied metaphysical framework of the polar opposites of heaven and hell, the domains of God and the Devil, as the context for human life, as they are by their authors' deliberate disablement of the usual sources of moral and religious authority, to allow the maximum freedom for (unwise) human choice, and to test to the utmost their protagonists' capacity to endure and respond to a tragic world in which evil is predominant and active.

The choice of an Italian or Spanish setting for five of the six tragedies (Faustus visits the Papal court at Rome, but the centre of his activities is the German university town of Wittenberg) already signals the characteristic focus of much Renaissance English tragic writing on disordered societies displaying extremes of passion, corruption and violence. Both Italy and Spain were associated in English audiences' minds with stereotypical extravagance of emotion, rigid codes of honour demanding private and comprehensive revenge for insult or injury, family feuds, extreme cruelty and violence. The Cambridge scholar Fynes Morrison solemnly reported the Italians' furious jealousy, their predilection for poison and bloodthirsty revenge, their lechery and their flattery. Thomas Nashe, in a famous passage in his fictional work The Unfortunate Traveller published in 1594, describes Italy as 'the paradise of the earth and the epicure's heaven'. It teaches impressionable young Englishmen, says Nashe, 'the art of atheism, the art of epicurising, the art of whoring, the art of poisoning, the art of sodomitry. . . . It is now a privy note among the better sort of men, when they would set a singular mark or brand on a notorious villain, to say, he hath been in Italy.' In Ford's 'Tis Pity She's a Whore, when the injured husband Soranzo declares 'the less I speak, the more I burn,/And blood shall quench that flame', his Spanish servant Vasques (who will later rejoice that a Spaniard outdid an Italian in revenge) congratulates him with the words, 'Now you begin to turn Italian'.

In the unsettled and fragile social world of these tragedies, children throw off parental restraint, servants bring about the 
destruction of their superiors, dukes and nobles neglect their public obligations in order to satisfy their personal ends. Antonio's glowing praise of the French court, with its 'fixed order' and 'judicious king', is positioned at the beginning of The Duchess of Malfi to set off by contrast the tyrannical and vicious rule of Ferdinand and his Cardinal brother. The conventionally ordered world of arranged marriages between social equals is everywhere disrupted: Bel-Imperia takes successive lovers; Faustus seeks a wife to satisfy his lust and is offered 'a hot whore', a devil woman sputtering fire and smoke; Gratiana can be persuaded to prostitute her daughter to Lussorioso; the servant De Flores finds an unlikely but natural partner in Beatrice-Joanna, while the courtiers Antonio and Franciscus seek to corrupt Alibius's wife. The Duchess of Malfi defies her brothers' authority and finds for herself a lover and a husband in her major-domo; Giovanni and Annabella break their father's heart with the discovery of their incestuous adulterous passion. Characters of simple faith or virtue, like the Old Man in Doctor Faustus or Castiza in The Revenger's Tragedy, are briefly tested then dismissed, with little or no moral effect on the world around them. Philotis in 'Tis Pity She's a Whore is made the tool of her uncle's revenge, then dismissed to a nunnery.

The religious landscape of these tragedies is dark and apocalyptic; life is lived out under the eye of a wrathful god or gods, and for many of the characters closes in punitive suffering and 'confusion', Ford's favourite word for final ruin and perdition. Webster's Duchess of Malfi and Ford's own Annabella meet their deaths with something like Hamlet's readiness, but the dramatists for the most part deny their characters dignity, clarity or self-knowledge in the hour of death. The world of The Spanish Tragedy is openly controlled by the spirit of Revenge, licensed by the King of Hell at the urging of his consort Proserpina. Despite the brief appearances of the Good Angel in Doctor Faustus, demons dominate the scenes and God is perceived only at an unreachable distance. It is possible to argue that Marlowe is projecting the world as seen through the haunted imagination of Faustus himself, but it is a perspective which denies any sense of equality between the forces of good and evil, religion and anti-religion, salvation and damnation. The strongest ethical and moral imperative in The Revenger's Tragedy is a medieval awareness of mortality, yet its most eloquent spokesman, Vindice, busily and paradoxically commits himself to winning a triumph over his enemies in the very pride of life whose futility he elsewhere 
denounces. It is possible to read the trials of the Duchess of Malfi as a prolonged process of spiritual purification through inordinate suffering, with Bosola's Judgement-Day fable of the Salmon and the Dogfish (3.5.121-37) occupying a crucial thematic position. But such a reading requires a position close to that of the contemporary Puritan divine William Perkins, who expresses the tough-minded belief that 'when God will send his own servants to heaven, he sends them in a contrary way, even by the gates of hell'. Certainly, the official representative of the Church, the Cardinal, is in many respects a stereotypical corrupt Catholic churchman, sensual and power-hungry, the persecutor rather than the protector of his own sister. Ford's Cardinal is little better. His protection of the assassin Grimaldi outrages both Donado and Florio, and his confiscation of the property of those slain at the end of the play, together with his brutal sentence of execution on Putana and his protection of Vasques is meant to outrage the audience. The Friar, who acts as spiritual adviser to both Giovanni and Annabella, fails to match his charges intellectually, and can do little more than threaten the erring couple with conventional images of hell-fire and damnation. Crucially, when he sees his own failure and 'the bad, fearful end' that lies before Giovanni, he leaves him to despair and hurries out of Parma to 'shun this coming blow', leaving Giovanni to find what moral strength he can draw from himself.

The Spanish Tragedy, the earliest play in this collection, begins the explicit exploration of the theme of hell on earth when in its opening lines the revengeful ghost of Andrea describes how after death in battle it descended to the court of Pluto and returned to earth accompanied by the hellish spirit of Revenge to watch out the convoluted destruction of his enemies and others. The play closes with their return 'to deepest hell' to complete the reward of the guiltless, and the torment of the guilty. Marlowe's Doctor Faustus 'confounds hell in Elysium' and commits himself to the demonic powers. When he naïvely asks Mephostophilis about the location of hell, he is told 'Hell hath no limits, nor is circumscribed/In one self place, for where we are is hell, / And where hell is must we ever be.' At the close of the play, a real hell gapes for him, and screaming to the demon who has companioned him for twenty-four years, he is borne away by devils. There is a memorable echo of this passage at the close of The Changeling, when De Flores holds the dying Beatrice-Joanna in his arms and acknowledges to the husband he has cuckolded, 'I coupled with your mate/At barley-break. Now we 
are left in hell.' Her father Vermandero, in a moment of general recognition characteristic of the close of a tragic play, comments, 'We are all there; it circumscribes us here.'

The Revenger's Tragedy offers a vision of what human life might be at its worst, deprived of all social, legal and moral restraints. Its mordant and revengeful observer, Vindice, introduces us to its doomed characters in language resonant with ideas of sin, damnation and the fires of hell:

\section{go, grey-haired adultery,}

And thou his son, as impious steeped as he,

And thou his bastard, true-begot in evil,

And thou his duchess, that will do with devil.

Four excellent characters! $O$ that marrowless age

Would stuff the hollow bones with damned desires,

And 'stead of heat, kindle infernal fires

Life in such a world lived out under the wrath of God, signalled by blazing stars and rolling thunder, becomes a living torment; the agonised and dying duke, held down and forced to watch his bastard son meeting his own wife 'for damned clips', asks, 'Is there a hell beside this, villains?'

The Duchess of Malfi, enduring the psychological tortures imposed on her by her brothers, perceives the continuation of life itself as the torment endured by the damned:

BOSOLA: Come, you must live.

DUCHESS: That's the greatest torture souls feel in hell, In hell; that they must live and cannot die.

In a stream of images of her imprisonment as a theatre, a cage, a tomb, a charnel-house, she describes the heaven over her head as 'made of molten brass,/The earth of flaming sulphur'. In a further image directly applicable to her torments, the second Madman tells the audience that 'Hell is a mere glasshouse, where the devils are continually blowing up women's souls on hollow irons, and the fire never goes out'. Bosola, watching her death throes invokes her 'fair soul' to return from darkness, 'and lead mine/Out of this sensible hell.' And the Cardinal, whose mind is much preoccupied with 
questions about hell, advises him to "Throw to the devil/Thy melancholy; the fire burns well,/What need we keep a stirring of it, and make/A greater smother?' It is a remark among many which suggestively associate the two brothers with evil and diabolical forces, setting out to destroy the goodness of their sister.

In Ford's 'Tis Pity She's a Whore, the Friar represents the orthodox religious view of their behaviour to the two young lovers: he associates Giovanni with those forward wits who 'Discovered first the nearest way to hell,/And filled the world with devilish atheism', and terrifies Annabella with a long set-piece description of the torments of an infernal hell. When his servant Vasques taunts Annabella's make-shift husband Soranzo with the question 'what do you think of your heaven of happiness now, sir?' the enraged husband declares, 'I carry hell about me; all my blood/Is fired in swift revenge.' At the close of the play, in a moment reminiscent of Othello's final questioning of Iago, the Cardinal demands of Vasques 'what incarnate fiend/Hath led thee on to this?' to which Vasques replies in terms disclaiming all association with a metaphysical evil, 'Honesty and pity of my master's wrongs'. We need not accept his profession of offended virtue - it is undercut by his delight in deception and his savagery - but it signals that there is no longer any need for stage demons of the kind Marlowe introduces; in the later tragedies of the period 'confusion' (a repeated word in this play) is brought down upon the characters by themselves.

If hell is the common metaphor in these plays for a world brought into existence by unchecked self-seeking expressed as a craving for power, control over others, sexual, emotional or intellectual self-satisfaction, tragic experience in such a world is focused on the consequent assault on the integrity of individual human personality and the hard-won wisdom progressively acquired both by the characters and the watching audience as more and more is lost.

In Hieronimo, we see a judge, finally unable to control his grief for the loss of his son, turning into a savage revenger no better than his enemies. The grand scholar Faustus, who aspires to deity itself and boasts of his 'manly fortitude' to Mephostophilis, finally rises to a frenzy of fear and despair, cursing his parents and envying the soulless, mindless life of the brute beasts. Vindice and his brother revenger Hippolito, at the beginning of The Revenger's Tragedy capable of moral horror and caustic indignation at the viciousness and lustfulness of the court, are gradually drawn into the lifestyle of scheming and self-gratification they condemn, progressively 
becoming more and more like those they hate. At the close of the play the audience is invited neither to pity nor to fear their fall, but to smile grimly as their self-adulatory cleverness overreaches itself. In the final moments of The Changeling, Beatrice-Joanna at last clearly recognises her own corruption, and the bewildered surviving characters led by Alsemero can do little more than list the astonishing transformations which have taken place in their lives beneath the changes of the moon. In Ford's 'Tis Pity She's a Whore, Giovanni, the brilliant student, the 'miracle of wit' solemnly challenged by his sister to 'Love me, or kill $\mathrm{me}^{\prime}$, finally and defiantly acts out a terrible 'rape of life and beauty', murdering and mutilating a love 'for whose each drop of blood/I would have pawned my heart'. Only the Duchess of Malfi outfaces the worst her brothers can inflict on her, and earns the final tribute of the play, 'Integrity of life is fame's best friend,/Which nobly, beyond death, shall crown the end.'

While the authors of most of these plays endorse the judgement of Vindice that 'When the bad bleeds, then is the tragedy good' (3.5.199) and gratify their audiences with scenes of physical and bloody violence, such manifestations of death and mutilation also serve to symbolise the assault on the integrity of personality which is the deeper theme of these tragedies. From Hieronimo's self mutilation to Giovanni's impalement of his sister's heart, the human body is brutalised, tortured and dismembered. Sometimes the violence is projected verbally rather than actualised, as when Ferdinand instructs the Duchess of Malfi to 'cut out thine own tongue' least it betray her lover, or when Vindice orders his brother to 'Let our two other hands tear up his lids/And make his eyes, like comets. shine through blood' if their victim refuses to look at the sight of his own wife's adultery they are forcing him to watch and acknowledge. But shocking stage spectacles in these tragedies are seldom merely gratuitous; they are mounted to force home both the appalling destructiveness of human wrongdoing and its moral implications. The body of Faustus is cut and bleeds, it loses a leg in a magic 'trick', it is torn apart by devils in actions analogous to and anticipating the final loss of his soul. Beatrice-Joanna is confronted with the all too physical evidence of the murder she has brought about in the ring-finger De Flores cuts from Piracquo, and in his turn De Flores is haunted by the image of his mutilated victim.

But in a culture which tolerated much physical pain and brutality (plays could be performed in bear-baiting amphitheatres) yet held 
reason to be the primary human faculty, the greatest threat to the integrity of the protagonists of these tragedies is the loss or subversion of rationality. Insistently in these tragedies an eruption of passionate emotion (associated in the Elizabethans' mind with 'blood') overthrows all the controls of reason and leads both to disaster and to madness. Kyd traces the destructive effects of obsessive grief on the mind of an old judge, Hieronimo, and his wife Isabella; both make deranged attacks on their unreachable enemies, the one in a court of law, the other at the scene of the crime, before Hieronimo succeeds in destroying his son's murderers in an ingenious but bloodthirsty way. Marlowe and his collaborator display the vacillating progress of a superb and adventurous mind driven towards the unthinkable by unexamined ambition, framing Faustus's tortured conscience with mindless admirers and exploiters of his powers. Like Hieronimo, Vindice, consumed by murderous grief, is arguably half-crazed; the thought of his wrongs 'Turns [his] abusèd heart-strings into fret'. Consequently, much of the bleakly comic power of The Revenger's Tragedy lies in its presentation of a corrupt, self-seeking group of aristocrats totally unaware of the activities of the psychopathic killer among them. The Changeling explicitly parallels the quest for emotional and sexual satisfaction in Vermandero's castle with sexual intrigues among the managers and patients of a hospital for the insane. The tragedy works by ironic inversion. In the apparent safety and stability of the castle world, the supposedly clear-eyed and coldly unattainable Beatrice-Joanna discovers her hidden capacity for criminality and sexual transgression. In the asylum, on the other hand, the stubbornly virtuous and clear-sighted Isabella exposes the mad folly of her disguised aristocratic lovers.

Webster's Duchess of Malfi is subjected to psychological torture in a deliberate and sustained assault on her reason. When a 'wild consort of madmen' from the common hospital fails to unsettle her mind she is strangled. Webster then proceeds to expose the irrational impulses driving her twin brothers' tyrannical and murderous behaviour. Ferdinand descends into absolute insanity; even the icily self-controlled Cardinal is troubled by the vision of 'a thing, armed with a rake,/That seems to strike at $\mathrm{me}^{\prime}$. Ford's Giovanni, characterised like Faustus as a brilliant student, commits himself to an absolute but incestuous love for his sister. Throughout the tragedy a vein of commentary describes both this and other lawless passions as a kind of madness: Giovanni is 'a frantic madman'; 
Soranzo's liaison with Hippolita is the result of 'distracted lust', provoked by his 'sensual rage of blood', and both these extremes are contrasted with the childish affection of the simpleton Bergetto for the innocent Philotis. Eventually Giovanni is trapped in the ways of the society he despises and murders his sister in a vain attempt to take revenge as others do. Ford daringly images his loss of all sense of reality as he brings on stage Annabella's heart, torn from her body and spitted on his dagger to display the 'truth' of a love he can find no other way to communicate to a disbelieving world. 'Rip up my bosom; there thou shalt behold/A heart in which is writ the truth I speak', he had earlier told his sister; his own final act is at once an affirmation and destruction of that truth, a tragic gesture of irrationality constructing itself as heroic defiance.

\section{When the Bad Bleeds, then is the Tragedy Good}

In the unjust world isolating the tragic pair of lovers, Vasques, the cunning and brutal Spanish servant who has brought about the poisoning of Hippolita, the dishonourable assassination of Giovanni and the blinding of Annabella's nurse Putana, is allowed to leave Parma without punishment, rejoicing that 'a Spaniard outwent an Italian in revenge'. So Ford makes his own distinctive use of a key narrative and thematic element in many of the tragedies of this period, a quest for bloody retributive justice.

Revenge plots have a universal appeal: they are found in such Greek and Roman tragedies as Euripides' Medea or Seneca's Thyestes, and they have enjoyed an enormous resurgence of popularity in the films, television dramas and detective stories of our own age. Kyd's Spanish Tragedy made such successful use of the theme in his own theatre that later writers took the arousal and satisfaction of revenge as a given narrative component of the form; in The Revenger's Tragedy Vindice describes vengeance as 'Murder's quit-rent' and 'tenant to Tragedy'.

Kyd's inventive play institutes the crucial elements of delay and frustration (for the audience as well as the protagonist) as the old judge Hieronimo first struggles to discover the identity of his murderous enemies and is then baulked in his attempts to reach them. The effects of frustration on the psyche of the avenger are registered in terms of desperate but apparently fruitless appeals to higher powers and an emotional apprehension of the world as wholly corrupt and degenerate, leading to incipient madness. The 
avenger is opposed by cruel and cunning enemies, who must be out-witted before they can be destroyed in a satisfyingly bloody and elaborate way. Kyd further delighted his audience by creating ironic situations and episodes of sudden and extreme violence brought about by complex cross-plotting (both in the sense of counterintrigues and the interlacing of separate revenge stories). Finally, he developed the intellectual aspect of the revenge theme through his characters' eloquent speculations about human and divine justice and the ethics of revenge.

Marlowe used the revenge theme more insistently in tragedits other than Doctor Faustus - notably in his bleakly comic play The Jew of Malta - but in Doctor Faustus the audience is aware from the start of the play of the slow gathering of divine retribution. The author of The Revenger's Tragedy exploits both the satiric possibilities of the theme in powerful monologues expressing Vindice's Hamlet-like melancholy and disgust at the corruption and mortality he sees all around him, and exciting narrative effects such as the biter-bitten pattern, deriving these from braided revenge plots springing out of two major crimes, the poisoning of Vindice's lover Gloriana and the rape of Antonio's wife.

In Middleton and Rowley's The Changeling, the traditional iconic figures of revenge are marginalised. Tomazo, Piracquo's avenging brother, does not arrive on stage until Act Five, Scene Two, with little opportunity to display his by now conventional profession of loss of all relish for the benefits of life; it is only in the very last scene of the play that Beatrice-Joanna's confession of her responsibility for the murder of Piracquo draws from her deceived husband Alsemero the kind of horror-stricken utterance which rings throughout The Spanish Tragedy:

$\mathrm{O}$, the place itself $\mathrm{e}^{\prime} \mathrm{er}$ since

Has been crying for vengeance: the temple

Where blood and beauty first unlawfully

Fired their devotion, and quenched the right one.

But the two dramatists have chosen to internalise the experience of retribution. It is Beatrice-Joanna's punishment to become 'the deed's creature'; in the arms of De Flores, as she recognises, 'Vengeance begins;/Murder is followed by more sins.' And at the close of the play it is not in the grip of stage demons or the spectre 
of Revenge but in the imagination of those left behind that her soul and that of her lover, transformed into 'black fugitives', are hurried away 'to take a second vengeance'.

Webster, too, chooses to delay the onset of revenge, allowing for two successive waves of retribution and placing the dark crime which initiates the second wave of retribution as late as the fourth act of his tragedy. First, the Cardinal and his brother fall upon their sister, after a long delay supposedly required to discover the identity of her lover Antonio. Having destroyed his sister, Ferdinand seeks to hunt down Antonio, feeding 'a fire great as my revenge,/Which ne'er will slack, till it have spent his fuel'. In a sequential counter-movement, the chief murderers are finally destroyed, but through a confused sequence of intentional plotting and accidental events which also take the lives of Antonio and Bosola. The dying Bosola may see his killing of Ferdinand as the perfection of his revenge on the main cause of his undoing, but Webster's world is one in which the powers of good and evil are almost equally balanced and retribution brings no satisfying triumphs for justice. In his friend John Ford's play 'Tis Pity She's a Whore, revenge-taking has become simply the normal response of passionate men and women in a society corrupt and lawless under its surface conventionalities; when Giovanni adopts the behaviour of the revenger he characteristically outgoes all others in the ritual cruelty of his actions and signifies his fall from fervent idealism to common corruption. Only his victimised sister, like the Duchess of Malfi, is left to claim the audience's pity.

In all of these tragedies Nemesis strikes at the lives of the characters, often brought down by their own or others' deliberate schemes of revenge. But in a way typical of tragedy, catastrophe is both explicable in terms of willed human action and incomprehensible in its apparently random invasion of human life. In these tragedies, revenge stories are the dramatists' principal means of dramatising the grand and universal theme of tragedy, the ancient mystery of evil, suffering and violent death.

\section{Public and Private Playhouses}

The plays in this anthology are all closely connected with the commercial theatre scene in London; they were written by authors who for the most part lived and worked in London, performed by resident London companies and printed for London publishers. 
More is known about the London theatres than about other theatrical venues outside the capital, but it should be remembered that many of the plays were also toured to provincial towns or given private performances in great country houses by travelling companies of actors; they were given command performances at court, they were acted by schoolboys and later by professional companies of young actors (known as 'Children'); they were staged by students at the universities of Oxford and Cambridge or the Inns of Court in London where lawyers were educated for their profession, and were sometimes taken to Europe by roving English companies.

In so many and such different locations, performance conditions might ranging from a makeshift stage on trestles in the courtyard of an inn or the floor-space of the large communal hall of a country house or university college to the arena of a public amphitheatre also used for bull or bear-baiting, or the specially constructed stage with its tiered seating in the Banqueting Hall in the palace at Whitehall. As they have always done, actors worked with whatever conditions they could find, and in his study of the much-performed Spanish Tragedy, D. F. Rowan usefully points out that 'some productions ... must have been mounted on the barest of scaffolds with perhaps only a traverse [curtain] at the back, while others were presented on permanent stages with trapdoors, backed by a two- or three-door tiring house façade, and topped with an upper acting area' (The Elizabethan Theatre V, ed. G. R. Hibbard [Ontario, London and Basingstoke, 1975] p. 114).

The first three plays in this collection, The Spanish Tragedy, Doctor Faustus and The Revenger's Tragedy, were originally performed in large public playhouses capable of holding almost 3000 people; circular or octagonal buildings, open to the sky, with a yard audience of about 800 standing in the open, crowded round the stage. More expensive seated accommodation was available in the three tiers of roofed galleries ranged round the standing yard and accessed from it by steps; later playhouses allowed for independent admission to the galleries by means of stairwells above the entrance-ways. Divided from these galleries and across the façade above the stage were high-priced 'lords' rooms' which offered a degree of privacy and a cushioned seat or stool and were accessed through the players' changing rooms. Contemporary evidence suggests that playgoers paid one penny to enter the yard, a further 
penny to be admitted to the galleries, and a third penny for a good view from the upper galleries. The lords' rooms cost sixpence.

A large platform stage (sometimes edged with a low railing) jutted out into the yard, raised about four feet above the yard floor and occupying almost a third of the space. For tragedies, it may have been draped with black. The contract for the Fortune Theatre, built in 1600, and modelled on the Globe, specified a stage 43 feet wide and 27 feet deep (12.9 $\times 8.1$ metres). A well-equipped stage had a trapdoor in the centre or towards the front of the stage, leading down to a notional hell below stage-level, or opening to allow actors or stage properties to rise into sight. On such a stage, surrounded on three sides by the standing audience, actors could establish a more immediate relationship with their audience than is possible on a stage separated from the auditorium by a proscenium arch; soliloquies and asides, frequent in Renaissance playtexts, show the dramatists and the actors exploiting the possibilities of such a relationship.

At the rear of the stage, facing the audience was the façade of the 'tiring-house' or actors' changing rooms. Two or three large doors led out onto the stage-space from this facade. At first-gallery level in the same façade, there was a gallery or balcony which could serve as an upper acting space or a place where musicians could play, or provide further seating for the wealthiest members of the audience. Earlier theatre historians argued for the general existence of an alcove or 'discovery space' at the centre of the façade, which could be closed off by a curtain (or 'traverse') or opened up as an inner stage area. The Globe certainly seems to have had such a shallow space for the display of static tableaux and other purposes, but a curtained booth with a rigid and firmly supported top set up between the two outer stage doors could serve equally well for such a purpose.

From above the highest gallery, covering and protecting the main stage from the weather, extended a canopy supported on two pillars; it was called 'the heavens', and its underside was painted with a sun, moon, stars, and possibly also the signs of the zodiac. Like the flies in a modern theatre, above it there was an enclosed space where sound and lighting effects could be produced, and from which properties like a heavenly throne could be winched down or the descent of a supernatural being safely managed.

The interior of the theatre was richly decorated and painted, but on stage there was a minimum of scenery and no attempt to create 
the detailed and realistic impression of a room or exterior usual in early modern theatres. Painted back-cloths or an arras could be hung up, and if required a stage property such as a 'state' (a throne set on a dais) could be quickly set out and removed again by stage-hands. The theatre manager Philip Henslowe's 1598 inventory of his stage-properties included a hell mouth, a 'dragon in fostes' (that is, for use in Doctor Faustus), a City of Rome (perhaps a back-cloth which, like 'a pope's mitre', might also have been used in the play), a tomb, a bay tree, a wooden canopy, a little altar and assorted foils. On a relatively bare and unlocalised stage, the audience's attention and imaginative involvement could be focused on the action rather than on the factitious lifelikeness of the set. Night scenes could be signalled by the introduction of lanterns or 'lights' (flaming torches). Both are used, for instance, in The Duchess of Malfi, and Hieronimo probably carried on a torch to signify the discovery of his murdered son by night. Stage effects of a spectacular kind were frequently introduced. In 1620, John Melton describes a visit to the Fortune in Golding Lane to see the tragedy of Doctor Faustus: 'There indeed a man may behold shag-haired devils run roaring over the stage with squibs in their mouths, while drummers make thunder in the tiring-house, and the twelve-penny hirelings make artificial lightning in the heavens.'

Performances usually began at 2 p.m. to take full advantage of daylight - a practice followed also in the private indoors theatres and in the absence of curtains to mask off the whole stage from the audience for a scene change, were continuous, allowing uninterrupted attention to the unfolding narrative. Not that the theatre audience lacked distractions: food and drink was on sale throughout the performance, tobacco smoking and noisy nut-cracking was common, there were outbursts of laughter, applause or hissing, the usual crowd noises, and disturbances occasioned by drunken behaviour or the activities of cutpurses (pickpockets) and prostitutes.

On the English stage, only male actors were permitted to perform, with boys or young men taking women's roles; in 1629 a visiting troupe of French actresses were 'hissed, hooted, and pippin-pelted from the stage' at the Blackfriars Theatre. Early actors caught and held their large audiences' attention with oratorical gesturing, full-voiced delivery, and stalking movements across the stage. The famous Edward Alleyn, who played the roles of Faustus and Tamburlaine, created an heroic gestural style of acting which lingered in the most plebeian public theatres like the Fortune and 
the Red Bull but was rapidly displaced among the leading public theatre companies as well as among those performing in the smaller and more sophisticated private playhouses by a more life-sized personation of individual character, particularly associated with Alleyn's famous contemporary, Richard Burbage, who played the roles of Hieronimo, Hamlet, Lear, and Ferdinand in Webster's Duchess of Malfi. The difference may be illustrated by a passage in a 1607 play describing an Alleyn-like 'stalking-stamping player, that will raise a tempest with his tongue, and thunder with his heels' compared with Thomas May's description in 1620 of Burbage's performance as Hieronimo in The Spanish Tragedy:

I have seen the knave paint grief In such a lively colour, that for false And acted passion he has drawn true tears From the spectators. Ladies in the boxes Kept time with sighs and tears to his sad accents, As had ie truly been the man he seemed.

(The Heir, 1.1)

But the players also held the eye with splendid and exotic costuming (sometimes given or sold to the actors at second or third hand by noble patrons or their servants). In a 1598 inventory of costumes in Alleyn's hand, 'faustus Jerkin his clok' is listed along with a scarlet cloak laid down with silver lace and silver buttons, a black silk gown with red flush, a yellow silk gown, french hose of silver panes laced with carnation satins laced over with silver, and cloth of gold for a boy. Little attention was paid to historical or ethnic accuracy in costuming (though it is likely that in Hieronimo's play the participants wore Turkish bonnets), but performers often donned familiar vocational costumes, like a friar's 'gown of gray', a cardinal's scarlet gown, or a soldier's coat. Edward Alleyn, who played the part of Doctor Faustus, did so 'in a surplice, with a cross upon his breast'; the woodcut in the 1616 edition of the play shows a more conventional scholarly costume, resembling the 'crimson gown striped with gold faced with ermine' in Alleyn's 1598 inventory of costumes. The boy playing Isabella in The Changeling, for the scene in which she pretends to be a madwoman, wore the 'habit' (costume) of 'a wild unshapen antic' (4.3.116).

As early as 1576 a new type of commercial indoors theatre appeared in London, the first Blackfriars Theatre. It was followed in 
1600 by the more famous second Blackfriars Theatre, acquired in 1609 by the King's Men as their winter home. Webster's Duchess of Malfi was played both there and at their public playhouse the Globe. The Changeling and 'Tis Pity She's a Whore were performed in yet another private playhouse, the Cockpit or Phoenix Theatre in Drury Lane, opened in 1617.

These were much smaller theatres than the public playhouses, usually taking the rectangular shape of an enclosed hall, and seating 600-700 spectators. The Blackfriars Theatre stage occupied the full width of the south end of the hall, though with boxes or lords' rooms at stage level on each side of the stage reducing its dimensions to about 28 square feet ( 8.4 metres square). For two shillings, ten or so members of the audience could hire stools and sit on each side of the stage itself; boxes cost half-a-crown. On the floor of the hall were padded bench seats, the most expensive of them immediately in front of the stage. Along the sides of the hall and across the rear wall ran two or three galleries; the cheapest seats cost sixpence and were in the top rear gallery at the furthest distance from the stage.

Such theatres were for a select and wealthy clientele: merchants and wealthier citizens and their wives, fashionable young men ('gallants'), law students, courtiers and members of the nobility and their attendants. Performances were given in the afternoon, and were interrupted by the need to regularly trim the candles which lit the hall. It became customary to provide string and woodwind chamber music before the beginning of the performance and in between the acts; the Blackfriars musicians played from a music-room above the stage, which could also double as a small upper stage from which a complacent Giovanni could watch his sister Annabella resist Soranzo's courtship on the main stage below. The Cockpit had a small tiring-house façade gallery from which Lollio watched an amorous Antonio court a frosty Isabella, and where madmen made their appearance acting out their own fantasies (3.3). Like the public theatres, these playhouses were equipped with trapdoors, and the tiring-house façade commonly provided a central double-doored entrance flanked by single-door entrances. A 'heaven' with concealed machinery could be suspended above the stage without the use of supporting pillars. A booth construction, or a curtain across the central entrance could create a discovery space serving as a shop, a tomb, a cell, a study, a closet or a display space for tableaux and static displays. On the stage of the 
Cockpit Theatre, Beatrice-Joanna was thrust into such an inner space with Alsemero's words 'Enter my closet;/I'll be your keeper yet' (The Changeling, 5.3 86-7).

While the smoke and din associated with the cannon and fireworks used in the open-air public theatres were inappropriate in the confined space of an interior theatre, stage properties and effects were used much as in the public theatres and could be even more elaborate, intended as they were for a more sophisticated audience. The Duchess of Malfi, performed in both public and private theatre venues, requires the discovery of an altar and shrine for the dumb-show in 3.4, life-sized effigies of Antonio and his children 'appearing as if they were dead' (4.1) and a tomb marking the Duchess's grave (5.3) from which the voice of the dead woman speaks, echoing Antonio's words. It is possible that for this scene the King's Men used a property-tomb already employed in The Second Maiden's Tragedy (1611) which allowed for a noise like a wind, clattering doors, the sudden opening of the tombstone and a great light appearing in the midst of the tomb to reveal 'his lady ... standing just before him all in white, stuck with jewels, and a great crucifix on her breast'. 


\section{Note on the Texts}

This anthology is intended for use by undergraduate students of English Renaissance drama, general readers and theatre practitioners rather than by scholars and research students needing access to exhaustive historical, bibliographical and textual information. Accordingly, the six play texts collected in this anthology are presented for reading with a minimum of editorial and explanatory intervention. Square brackets are used in the texts to indicate substantive emendation or addition; the existence of explanatory notes is signalled within the texts by a superscript circle $\left({ }^{\circ}\right)$; the notes themselves are supplied at the end of each text.

In each instance I have selected as copytext a representative of the first (and usually unique) authoritative edition; the accretions and unauthorised changes made during the working life of the companies which performed the plays are not recorded, with the exception of two major and representative examples from The Spanish Tragedy and Doctor Faustus (see Appendix I and II). In editing the texts, I have consulted the most recent textual scholarship, in particular the editions listed in the introductory notes to each play, but I do not record textual variants between individual copies of the plays (quartos) or between successive editions; nor in general do I record the history of and authority for necessary and substantive corrections made to the original texts. These may be conveniently studied in the textual collations provided in the Revels editions of the six plays concerned here, or in the very full collations supplied in such new standard collected editions as the Clarendon Press Marlowe (1987- ) or the Cambridge Webster (1995- ).

With the exception of the prefatory material appearing with two plays, The Duchess of Malfi (1623) and 'Tis Pity She's a Whore (1633), the complete texts of the original quarto editions are given in this anthology. Webster's and Ford's tragedies were equipped with prose dedications by their authors to potential or actual aristocratic 
patrons, and with commendatory poems by friends and supporters. Webster addressed his tragedy to George Harding, the thirteenth Baron Berkeley (1601-58), whose maternal grandfather and father had been patrons of the Lord Chamberlain's Men, the company taken under the patronage of King James in 1603 as the King's Men, and the players who first performed his tragedy. Ford dedicated his play to John Mordaunt (c.1599-1643), who had recently been created first Earl of Peterborough (1628) and from the dedication seems to have given particular but unknown favours to the dramatist. Webster's poetic supporters were Thomas Middleton, William Rowley and John Ford, with all of whom at various times Webster worked on team-written plays, a common practice in the theatre industry then as now. Little is known of Thomas Ellice, Ford's single admirer, other than that he was the brother of an Inns of Court man who shared the dedication of another of Ford's plays, The Lover's Melancholy (1629).

The play-texts are presented in a normalised and modernised form. That is, standardised layout, font and print conventions in the use of italics and capitals for act and scene indications, speech headings and scene directions have been imposed on the variety of practices in the original texts. Act and scene directions are given a standard form (as, Act One, Scene One) and editorial intervention to mark new scene divisions following standard modern practice is not noted in the Commentary. All original asides are printed in italics within curved brackets; asides added by the editor are distinguished by square brackets. The various forms of past participles in these texts are reduced to -ed or -èd; the first is not pronounced as an extra syllable, the second is.

A number of other changes are made silently. Spellings are modernised (burthen becomes burden, ile becomes I'll), and names are given a consistent and usual modern-spelling form, both to avoid what Gāmini Salgādo calls a bogus 'archaism' in the reader's response and to regularise different spelling practices among authors and printing-house compositors. (For instance, the various spellings of the name of Doctor Faustus's familiar spirit are reduced to Mephostophilis.)

The frequent seventeenth-century practice of introducing capital letters to mark an emphasis or signal a grammatical form is replaced by modern print conventions. Wherever possible, the original punctuation of the dialogue is retained since it may preserve valuable indications of how the actor was meant to deliver the lines, 
as well as providing grammatical indicators. However, Elizabethan and Jacobean punctuation can be erratic or obscure to modern readers and actors, and in many cases it reflects the inconsistent practice of printers rather than that of the author. Accordingly, punctuation is silently modernised where the original pointing of the texts is plainly deficient or misleading.

Where they are missing in the original text (and no Renaissance publisher thought it necessary to supply a full record of contemporary stage practice), necessary or implied stage directions are supplied in square brackets, and although such familiar Latin directions as Exit and Exeunt omnes ('the stage is cleared of all actors') are retained, more elaborate or unfamiliar Latin directions are translated into English. Passages in a language other than English are retained in the body of the text, but a translation is supplied in the notes on the play.

The general intention is provide readers, performers and playgoers with readily accessible texts, accompanied with sufficient information to create, in John Webster's words, in the dedication of his first great tragedy, The White Devil (1612) 'that which is the only grace and setting out of a tragedy, a full and understanding auditory'. 